\title{
ENTERIC PARASITES AND HIV INFECTION: OCCURRENCE IN AIDS PATIENTS IN RIO DE JANEIRO, BRAZIL
}

\author{
H. MOURA $/^{* *}$, O. FERNANDES, J. P. B. VIOLA, S. P. SILVA, R. H. PASSOS* \& D. B. LIMA* \\ Universidade do Estado do Rio de Janeiro, Faculdade de Ciências Médicas, Departamento de Patologia e \\ Laboratórios, Parasitologia * Hospital Universitário Pedro Ernesto, Departamento de Medicina Interna, \\ Doenças Infecciosas e Parasitárias, Avenida 28 de Setembro, 87-F, 59, 20551, Rio de Janeiro, RJ, Brasil \\ ** Hospital Evandro Chagas, FIOCRUZ, Serviço de Parasitologia, Caixa Postal 926, 20001 Rio de Janeiro, RJ, \\ Brasil
}

The occurrence of intestinal parasites, its relation with the transmission mechanism of HIV, and the clinical state of the AIDS patients, were analyzed in 99 Group IV patients (CDC, 1986), treated at "Hospital Universitário Pedro Ernesto"(HUPE), between 1986 and 1988.

The group consisted of 79 (79.8\%) patients whose HIV transmission mechanism took place through sexual contact and of $16(20.2 \%$; who were infected through blood.

Feces samples from each patient were examined by four distincts methods (Faust et al., Kato-Katz, Baermann-Moraes and Baxby et al.).

The most occurring parasites were: Cryptosporidium sp., Entamoeba coli and Endolimax nana (18.2\%), Strongyloides stercoralis and Giardia lamblia (15.2\%), E. histolytica and/or E. hartmanni $(13.1 \%)$, Ascaris lumbricoides (11.1\%) and Isospora belli (10.1\%). Furthermore, $74.7 \%$ of the patients carried at least one species.

Intestinal parasites were found in $78.5 \%$ of the patients who acquired the HIV through sexual intercourse and in 56.3\% of those infected by blood contamination. The difference, was not statistically significant $(p>0.05)$.

In the group under study, the increase of the occurrence of parasitic infections does not seem to depend on the acquisition of HIV through sexual contact. It appears that in developing countries, the dependancy is more related to the classic mechanisms of parasites transmission and its endemicity.

\footnotetext{
Key words: HIV and intestinal parasites - AIDS - Cryptosporidium sp. - Isospora belli - sexually transmited parasites
}

The Acquired Immunodeficiency Syndrome (AIDS) was first registered in Brazil in 1982 (Rodrigues \& Chequer, 1988). From that year on, up to February of $1989,5,712$ cases were reported. Around $81.1 \%$ of them were detected in the southeast region of Brazil $-62.5 \%$ of the cases occurred in the state of São Paulo while $14.1 \%$ appeared in the state of Rio de Janeiro (Ministério da Saúde, 1989).

It is well known that several etiological agents such as, endogenous viruses, facultative

Received May 29, 1989.

Accepted September 15, 1989. intracellular microorganisms, fungi and protozoa, certain bacteria and even helminths affect AIDS patients (Blaser \& Cohn, 1986). Secondary infections may occur through the acquisition of opportunistic organisms or by the reactivation of latent infections (WHO, 1988).

Parasitic infections present a high morbidity rate among Human Immunodeficiency Virus (HIV) infected persons, even in developed countries where they are rare (Cunningham et al., 1988; Gotzche et al., 1988; Laughton et al., 1988; Smith et al., 1988). Diarrhea is a common manifestation during the development 
of the AIDS disease. Besides the usual forms of human contamination, intestinal parasites can be sexually transmitted among homosexual partners (Quinn, 1986).

As the prevalences of parasitic and HIV infections are very high in third world countries, an informal consultation, co-sponsored by the UNDP/WORLD BANK/WHO Special Programme for Research and Trainning in Tropical Diseases (TDR) and the Global Programme on AIDS (GPA), was held at the Kenya Medical Research Institute in December of 1987, in order to discuss the interrelations between tropical diseases and the HIV infections (WHO, 1988).

The scarce information on the combined interrelations between intestinal parasites and the HIV infection in tropical countries led us to present these data, which were obtained from patients under care at HUPE (University Hospital), Rio de Janeiro, Brazil, during the period from 1986 to 1988 .

\section{MATERIAL AND METHODS}

Out of 99 patients analysed, 89 were male and 10 female, varying in age from 18 to 70 , giving an avarage age of 38.6.

These cases were studied during the years of 1986, 1987 and 1988, in the Parasitic and Infectious Diseases Branch of HUPE, which belongs to Universidade do Estado do Rio de Janeiro (UERJ).

A full history was taken from each patient who, in turn, was thoroughly examined. The cases in question were classified according to the criteria utilized by the Centers for Disease Control (CDC, 1986). Furthermore, only those patients belonging to Group IV were studied.

A minimum of 1 and a maximum of 3 stool samples were analyzed for each patient. The samples were examined for parasites by means of microscopy, including Cryptosporidium $s p$.

The specimens were submitted to four concentration techniques, such as zinc sulphate centrifugal flotation (Faust et al., 1939), thick smear (Katz et al., 1972), larvae recovery (Moraes, 1948) and hot saphranin staining of stool concentrates by formalin-ether centrifuga- tion technique (Ritchie, 1948; Baxby et al., 1984).

Simultaneously coproscopy results of HUPE adult patients, whose examinations were performed, dúring the same period, were compiled, for the purpose of observing the occurrence of intestinal parasites in the population that usually request the services of the HUPE. In this methodology, the research for Cryptosporidium sp. was not performed.

The collected data were statistically analyzed by the chi-square test.

\section{RESULTS}

From 99 Group IV AlDS patients registered at HUPE for treatment, $74(74.7 \%)$ were carriers of at least one species of intestinal helminth or protozoa.

In Table I, different species of protozoa found in each patient are presented. The patients, in turn, were classified both, according to the way they acquired the HIV - sexually or by blood contamination - and, also, by their clinical state at the time their stools were taken for analysis.

Identical procedure was carried out in the formation of Table II. However, the helminths encountered in each patient were accounted for this time.

It is worth mentioning that these tables also include the results obtained from the 260 adult HUPE patients.

It can be observed from Tables 1 and II that 11 species of protozoa and 5 species of helminths were detected in the AIDS patients studied.

The most frequently enteric parasites were Cryptosporidium sp., Entamoeba coli and Endolimax nana (18 patients each); followed by Strongyloides stercoralis and Giardia lamblia (15 patients each); E. histolytica and/or E. hartmanni (13 patients); Ascaris lumbricoides (11 patients) and Isospora belli (10 patients).

When the presence of either protozoa or helminths was correlated to the way the patient acquired the HIV it was observed that 62 (78.5\%) of those who acquired the HIV 
TABLE I

Intestinal protozoa observed in 99 group IV AIDS patients according to acquisition of HIV and clinical state; and in adult patients - HUPE, UERJ, Brazil - 1986-1988

\begin{tabular}{|c|c|c|c|c|c|c|c|c|c|c|}
\hline \multirow{2}{*}{ Protozoa } & \multirow{2}{*}{$\begin{array}{c}\text { Types of HIV transmission } \\
\text { Clinical classification }\end{array}$} & \multicolumn{3}{|c|}{ Sexual } & \multicolumn{3}{|c|}{ Sanguineous } & \multirow{2}{*}{$\begin{array}{l}\text { Unidentified } \\
\text { transmission } \\
\quad(N=4)\end{array}$} & \multirow{2}{*}{$\begin{array}{c}\text { Number of } \\
\text { cases } \\
(\mathrm{N}=99)\end{array}$} & \multirow{2}{*}{$\begin{array}{c}\text { Hupe adult } \\
\text { patients } \\
(\mathrm{N}=260)\end{array}$} \\
\hline & & $\begin{array}{c}\text { IV }_{A} \\
(N=12)\end{array}$ & $\begin{array}{c}I_{\mathrm{B}}, \mathrm{C}, \mathrm{D} \\
(\mathrm{N}=67)\end{array}$ & $\begin{array}{c}\text { Total } \\
(N=79)\end{array}$ & $\begin{array}{c}\mathrm{IV}_{\mathrm{A}} \\
(\mathrm{N}=1)\end{array}$ & $\begin{array}{c}\mathrm{IV}_{\mathrm{B}, \mathrm{C}, \mathrm{D}} \\
(\mathrm{N}=15)\end{array}$ & $\begin{array}{c}\text { Total } \\
(\mathrm{N}=16)\end{array}$ & & & \\
\hline \multicolumn{2}{|c|}{ Cryptosporidium sp. } & 0 & $14(20.9 \%)$ & $14(17.7 \%)$ & 0 & $3(20 \%)$ & $3(18.8 \%)$ & $1(25 \%)$ & $18(18.2 \%)$ & * \\
\hline \multicolumn{2}{|c|}{ Endolimax nana } & $2(16.7 \%)$ & $15(22.4 \%)$ & $17(21.5 \%)$ & 0 & $1(6.7 \%)$ & $1(6.3 \%)$ & 0 & $18(18.2 \%)$ & $25(9.6 \%)$ \\
\hline \multicolumn{2}{|c|}{ Entamoeba coli } & $3(25 \%)$ & $11(16.4 \%)$ & $14(17.7 \%)$ & 0 & $4(26.7 \%)$ & $4(25 \%)$ & 0 & $18(18.2 \%)$ & $14(5.4 \%)$ \\
\hline \multicolumn{2}{|c|}{ Giardia lam blia } & $1(8.3 \%)$ & $13(19.4 \%)$ & $14(17.7 \%)$ & 0 & $1(6.7 \%)$ & $1(6.3 \%)$ & 0 & $15(15.2 \%)$ & $3(1.2 \%)$ \\
\hline \multicolumn{2}{|c|}{ Entamoeba histolytica and/or $E$. hartmanni } & $4(33.3 \%)$ & $7(10.4 \%)$ & $11(13.9 \%)$ & 0 & $2(13.3 \%)$ & $2(12.5 \%)$ & 0 & $13(13.1 \%)$ & $1(0.4 \%)$ \\
\hline \multicolumn{2}{|c|}{ Isospora belli } & 0 & $8(11.9 \%)$ & $8(10.1 \%)$ & 0 & $1(6.7 \%)$ & $1(6.3 \%)$ & $1(25 \%)$ & $10(10.1 \%)$ & 0 \\
\hline \multicolumn{2}{|c|}{ Iodamoeba bütschlii } & $1(8.3 \%)$ & $2(3 \%)$ & $3(3.8 \%)$ & 0 & 0 & 0 & 0 & $3(3 \%)$ & 0 \\
\hline \multicolumn{2}{|c|}{ Blastocystis hominis } & 0 & $2(3 \%)$ & $2(2.5 \%)$ & 0 & 0 & 0 & 0 & $2(2 \%)$ & 0 \\
\hline \multicolumn{2}{|c|}{ Sarcocystis sp. } & 0 & 0 & 0 & 0 & 0 & 0 & $1(25 \%)$ & $1(1 \%)$ & 0 \\
\hline \multicolumn{2}{|c|}{ Dientamoeba fragilis } & 0 & $1(1.5 \%)$ & $1(1.3 \%)$ & 0 & 0 & 0 & 0 & $1(1 \%)$ & 0 \\
\hline \multicolumn{2}{|c|}{ Chilomastix mesnilii } & 0 & $1(1.5 \%)$ & $1(1.3 \%)$ & 0 & 0 & 0 & 0 & $1(1 \%)$ & 0 \\
\hline
\end{tabular}

* A technique for the detection of Cryptosporidium sp. was not utilized for the HUPE adult patients.

\section{TABELA II}

Intestinal helminths observed in 99 group IV AIDS patients according to acquisition of HIV and clinical state; and in adult patients - HUPE, UERJ, Brazil - 1986-1988

\begin{tabular}{|c|c|c|c|c|c|c|c|c|c|c|}
\hline \multirow{2}{*}{ Helminths } & \multirow{2}{*}{$\begin{array}{c}\text { Types of HIV transmission } \\
\text { Clinical classification }\end{array}$} & \multicolumn{3}{|c|}{ Sexual } & \multicolumn{3}{|c|}{ Sanguineous } & \multirow{2}{*}{$\begin{array}{l}\text { Unidentified } \\
\text { transmission } \\
\qquad(\mathrm{N}=4)\end{array}$} & \multirow{2}{*}{$\begin{array}{c}\text { Number of } \\
\text { cases } \\
(N=99)\end{array}$} & \multirow{2}{*}{$\begin{array}{l}\text { Hupe adult } \\
\text { patients } \\
(\mathrm{N}=260)\end{array}$} \\
\hline & & $\begin{array}{c}\mathrm{IV}_{\mathrm{A}} \\
(\mathrm{N}=12)\end{array}$ & $\begin{array}{c}\mathrm{IV}_{\mathrm{B}, \mathrm{C}, \mathrm{D}} \\
(\mathrm{N}=67)\end{array}$ & $\begin{array}{c}\text { Total } \\
(N=79)\end{array}$ & $\begin{array}{c}\mathrm{IV}_{\mathrm{A}} \\
(\mathrm{N}=1)\end{array}$ & $\begin{array}{c}\mathrm{IV}_{\mathrm{B}, \mathrm{C}, \mathrm{D}} \\
(\mathrm{N}=15)\end{array}$ & $\begin{array}{c}\text { Total } \\
(\mathrm{N}=16)\end{array}$ & & & \\
\hline \multicolumn{2}{|c|}{ Strongyloides stercoralis } & 0 & $12(17.9 \%)$ & $12(15.2 \%)$ & 0 & $1(6.7 \%)$ & $1(6.3 \%)$ & $2(50 \%)$ & $15(15.2 \%)$ & $17(6.5 \%)$ \\
\hline \multicolumn{2}{|c|}{ Ascaris lumbricoides } & $1(8.3 \%)$ & $9(13.4 \%)$ & $10(12.7 \%)$ & 0 & 0 & 0 & $1(25 \%)$ & $11(11.1 \%)$ & $18(6.9 \%)$ \\
\hline \multicolumn{2}{|c|}{ Ancilostomatidae } & $2(16.7 \%)$ & $5 \quad(7.5 \%)$ & $7(8.9 \%)$ & 0 & 0 & 0 & $1(25 \%)$ & $8(8.1 \%)$ & $4(1.6 \%)$ \\
\hline \multicolumn{2}{|c|}{ Trichuris trichiura } & 0 & $6(8.9 \%)$ & $6(7.6 \%)$ & 0 & 0 & 0 & 0 & $6(6.1 \%)$ & $24(9.2 \%)$ \\
\hline \multicolumn{2}{|c|}{ Enterobius vermicularis } & 0 & $1(1.5 \%)$ & $1(1.3 \%)$ & 0 & 0 & 0 & 0 & $1 \quad(1 \%)$ & $1(0.4 \%)$ \\
\hline
\end{tabular}


sexually and $9(56.3 \%)$ of those who were infected by the HIV through blood contamination carried intestinal parasites. The difference between these two groups, however, was not statystically significant.

In the group of patients who hosted parasites and who had contracted AIDS sexually, $34(54.8 \%)$ carried one specie of intestinal parasite. Similarly, another $10,7,9$ and 2 patients carried, each, 2, 3, 4 and 5 different species of intestinal parasites, respectively.

Comparatively, in the blood contaminated HIV group, 1 species of intestinal parasite was identified in $6(66.7 \%)$ patients while 2 species were detected in 2 patients and 3 species were observed in 1 patient.

Statistical analysis was performed by comparing the two groups of AIDS patients, those who got it either sexually or through blood contamination. This analysis, taking each parasite for each group as a parameter, turned out to be not significant.

\section{DISCUSSION}

The group studied was composed of 79 $(79.8 \%)$ patients who contracted the HIV through sexual intercourse and of $16(20.2 \%)$ patients who were infected by blood contami. nation.

The ratio between the two types of HIV acquisition observed in this study, measured in percentage, matches, coincidentally, that for the entire population of HUPE AIDS patients, which in turn reflects approximately the way in which AIDS is transmitted in Brazil (Ministério da Saúde, 1989).

The data gathered in this study were obtained after a routine for the diagnosis of parasitic infections, in positive HIV patients, was established (Moura et al., 1987).

This routine consisted of a coupling between classic and specific techniques for the detection of helminth eggs and larvae, cysts of protozoa and, also, of a special staining procedure for the detection of Coccidia. Despite its great specificity, the technique failed to diagnose certain cases, which is a signal that the development of more sensitive techniques is necessary (Baxby et al., 1984; Gotzsche et al., 1988).
The great variety and frequency of parasitic species found in the AIDS patients studied can be seen as the present state of endemic diseases in developing countries (WHO, 1988).

Two out of the three most frequently diagnosed protozoa are not considered pathogenic, even in immunocompromissed patients. On the other hand, Cryptosporidium sp. has been occurring with high incidence in immunocompromissed patients, since a few years back. This fact became more evident after a better standard procedure for diagnostic techniques was developed and, also, after Cryptosporidium $s p$. was characterized as opportunistic, in AIDS patients (Soave et al., 1984; Weikel et al., 1985; Soave \& Armstrong, 1986; Luna et al., 1987).

In the group studied, a rate of $18.2 \%$ of Cryptosporidium sp. was registered, considered high when compared to rates from the Centers for Disease Control which vary from $3.6 \%$ to $11 \%$ (Navin \& Hardy, 1987). High rates were also related by Luna et al. (1987) using the same methodology, which revealed that $17.3 \%$ out of 130 patients from an AIDS risk group were carriers of Cryptosporidium sp.

In São Paulo (Brazil), Dias et al. (1988a) related $12 \%$ positiveness in the feces of patients diagnosed as having AIDS. Perhaps, this fact can be explained by the dilution of the positiveness in the sample studied by Dias et al. (1988b). This sample contained a great number of Group II HIV-positive patients.

Isospora belii, which used to be registered in about $0.5 \%$ of the populations studied until the infection by HIV became known, began to be found frequently in AIDS patients (Pessoa \& Martins, 1980; Dehovitz et al., 1986).

In the present study, 10 patients $(10.1 \%)$ were affected by this Apicomplexa, which agrees with the findings of Luna et al. (1987).

The discovery of a patients which Sarcocystis sp. was possible by routine research for Coccidia. A more profound study must be carried out, in order to better characterize the Sarcocystis prevalence in HIV carriers, either as an intestinal parasite or as a tissue pathogen.

Giardia lamblia has been insistently referred to a sexually transmissive parasite. This, by itself, could justify the ratio of $15 \%$ observed, 
since $79.7 \%$ of the population under study can be considered as belonging to a risk group, consisting of anal intercouse and oral-anal contact practioners (Meyer \& Jarrol, 1980; Turner, 1985). This fact, though, was not statistically proved in this study.

In 1987, Luna et al. related that the amount of giardiasis in AIDS patients was three times higher when compared to a control group of adult patients having diarrhea. According to Coura (1987) such data strongly show the increase in the morbidity and prevalence of giardiasis in AIDS cases, although Dias et al. (1988a) did not notice any difference between AIDS patients and patients belonging to a control group in São Paulo, since the parasite has great endemicity in that state.

Entamoeba histolytica is nowadays characterized as a pathogen transmitted through sexual contact, a fact that when associated to its own endemicity explains the discovery of such protozoa, with tetranucleated cysts, in $11.5 \%$ of the patients analyzed. Tetranucleated cysts found in human feces do not imply in the diagnosis of $E$. histolytica, because $E$. hertman$n i$ also has this kind of resistance form. In this study the morphological differentiation between the two species was not done.

Although $E$. histolytica is frequently found in homosexuals, it functions as a comensal in those individuals and has always belonged to the non-pathogenic zymodemas, according to studies already done in other countries (Allanson-Jones et al., 1988).

Among helminths, the presence of S. stercoralis in $15.6 \%$ of the group under study should be stressed. Since the study dealt with immunocompromissed patients, instances of disseminated strongiloidiasis would be more commonly expected. Probably, they could not be detected due to the lack of necropsies performed. Quinn (1986) discussed the possibility of $S$. stercoralis transmission by oral-anal contact since filariform larvae can be eliminated in the feces and stay, as a result, in the perianal region. Thus, the increase in the incidence of intestinal strongiloidiasis in the group could be explained this way.

The data presented in this study document the high prevalence of intestinal parasites in HIV carriers, with results that turned to be stastistically significant $(\mathrm{p}<0.05)$, when compared which HUPE adult patients. Regarding the way the HIV was contracted by the AIDS patients, through blood or sexual contact - there was not any statistically significant difference between the two categories.

Although this fact occurred, the transmission of parasites via sexual intercourse is a reality (Meyer \& Jarrol, 1980; Quinn, 1986; Allanson-Jones et al., 1988; Cunningham et al., 1988). It should be remembered, on the other hand, that in developing countries, such as in Brazil, the contamination of parasites, through classic mechanisms, is so important - due to the infectious pressure present in the environment - that it makes the other mechanisms appear as secondary.

Another approach to these data can be done by considering the high incidence, reported above, as a reflection of the alteration, in a advanced stage, of the immune system, since in the present study all the AIDS patients belonged to Group IV. At this level, the defense mechanisms are very much compromissed, which can facilitate the establishment of parasites and other infectious agents (FernandezCruz et al., 1988; Miranda-Silva et al., 1988).

The great variety of parasitic species identified in the AIDS patients studied lead us to recommend that a greater number of prospective studies be done, mainly in developing countries. Furthermore, these studies should be carried out with the participation of a large number of patients. In addition, the methodology used for the diagnosis of parasites should fulfill the highest sensibility and specifity criteria.

It is the common belief of all participants in this study that the interrelations between parasitic diseases and HIV infection will be more easily done after the correlation between the data related to the prevalence and the evolution of the parasitic infections in AIDS patients is performed.

\section{RESUMO}

Parasitas entéricos e infecção pelo HIV: ocorrência em pacientes com SIDA/AIDS no Rio de Janeiro, Brasil - A ocorrência de parasitos intestinais, sua relação com o mecanismo de transmissão do HIV e a apresentaçāo clínica da 
AIDS foram analisadas em 99 pacientes do grupo IV (CDC, 1986), atendidos no Hospital Universitário Pedro Ernesto (HUPE) entre 1986 e 1988.

O grupo era constituído de $79(79,9 \%)$ pacientes cujo mecanismos de transmissāo do HIV se deu por via sexual e de $16(20,2 \%)$ que se infectaram por via sanguínea.

Amostras de fezes de cada paciente foram examinadas por quatro métodos distintos (Faust et al., Kato-Katz, Baermann-Moraes e Baxby et al.).

Os parasitos mais freqüentemente encontrados foram: Cryptosporidium sp., Entamoeba coli e Endolimax nana (18,2\%) seguidos de Strongyloides stercoralis e Giardia lamblia $(15,2 \%), E$. histolytica e/ou E. hartmanni $(13,1 \%)$, Ascaris lumbricoides $(11,1 \%)$ e Isospora belli $(10,1 \%)$, sendo que $74,4 \%$ dos pacientes com AIDS albergavam pelo menos uma espécie.

Observamos que $78,5 \%$ dos pacientes que adquiriram o HIV por via sexual e $56,3 \%$ dos que foram infectados por via sanguínea albergavam parasitos intestinais, mas a diferença não foi estatisticamente significativa $(\mathrm{p}>0,05)$.

O mecanismo de infecçāo por via sexual não parece contribuir de forma importante para o aumento da ocorrência de infecções parasitárias no grupo estudado e sim os mecanismos clássicos de transmissão de parasitos em nosso meio.

Palavras-chave: HIV e parasitoses intestinais SIDA/AIDS - Cryptosporidium sp. - Isospora belii parasitos transmitidos sexualmente

\section{ACKNOWLEDGMENTS}

To Jorge Soares and Marilene Adão de Paula for their technical assistance; to Antonio Miguel Haddad and Caroline Rouzeré for the English review and to José Roberto Machado e Silva for comments on the manuscript.

\section{REFERENCES}

ALLANSON-JONES, E, MINDLL, A.; SARGEAUNT, P. \& KATZ, D., 1988. Outcome of untreated infection with Entamoeba histolytica in homosexual men with and without HIV antibody. Brit. Med. J., 297: 654-657.

BAXBY, D.: BRUNDEL, N. \& HART, C. A., 1984. The development and performance of a simple, sensitive method for the detection of Cryptospo- ridium oocysts in faeces. J. Hyg. Camb., 93: 317323.

BLASER, M. J. \& COHN, L. D., 1986. Opportunistic infection in patients with AIDS: clues to the epidemiology of AIDS and the relative virulence of pathogens. Rev. Infect. Dis., 8:21-30.

CENTERS FOR DISEASE CONTROL (CDC), USA, 1986. Classification system for human T-limphotropic virus type III/lymphadenophathy associated virus infections. Morbid. Mortal. Weekly. Rep., 35: 334-339.

COURA, J. R., 1987. Parasitoses nos portadores de AIDS. J. Bras. Med., 53:42-54.

CUNNINGHAM, A. L.; GROHMAN, G. S.; HARKNESS, J.; LAW, C.; MARRIOTT, D.; TINDALL, B. \& COOPER, D. A., 1988. Gastrointestinal viral infections in homosexual men who were symptomatic and seropositive for human immunodeficiency virus. J. Infect. Dis., 158: 386-391.

DEHOVITZ, J. A.; PAPE, J. W.; BONCY, M. \& JOHNSON Jr., W. D., 1986. Clinical manifestations and therapy of Isospora belli infection in patients with the acquired immunodeficiency syndrome. N. Engl. J. Med., 315: 87-90.

DIAS, R. M. D.; MANGINI, A. C. S.; TORRES, D. M. A. G. V.; CORREA, M. O. A.; LUPETTI, N.; CORREA, F. M. A. \& CHIEFFI, P. P., 1988a. Cryptosporidiosis among patients with acquired immunodeficiency syndrome (AIDS) in the country of São Paulo, Brazil. Rev. Inst. Med. Trop. Sāo Paulo, 30: 310-312.

DIAS, R. M. D. S.; PINTO, W. P.; CHIEFFI, P. P.; MANGINI, A. C. S.; TORRES, D. M. A. G. V.; DEL BIANCO, R. \& FERRARI, L., 1988b. Enteroparasitoses em pacientes acometidos pela síndrome de imunodeficiência adquirida (AIDS/SIDA). Rev. Inst. Adolfo Lutz, 48:63-67.

FAUST, E. G.; SAWITZ, W.; TOBIE, J.; ODOM, V.; PERES, C. \& LINCICOME, R. D., 1939. Comparative efficiency of various technics for the diagnosis of protozoa and helminths in feces. J. Parasitol., 25: 241-262.

FERNANDEZ-CRUZ, E.; FERNANDEZ, A. M.; GUTIERREZ, C.; GARCIA-MONTES, M.; MORENA, T.; RODRIGUEZ-VILLANUEVA, J.; LONGO, N. \& ZABAY, I. M., 1988. Progressive cellular impairment leading to development of AIDS: two-year prospective study of HIV infection in drug addicts. Clin. Exp. Immunol., 72: 190-195.

GOTZSCHE, P. C.; BYGBJERG, I. C.; OLESEN, B.; MOLLER, L. H.; SALIM, Y. S. \& FABER, V., 1988. Yield of diagnostic tests for opportunistic infections in AIDS: a survey of 33 patients. Scand. J. Infect. Dis., 20: 395-402.

KATZ, N.; CHAVES, A. \& PELlEGRINO, J., 1972. A simple device for quantitative stool thick-smear technique in schistosomiasis mansoni. Rev. Inst. Med. Trop. Sāo Paulo, 14: 357-400.

LAUGHON, B. E.; DRUCKMAN, D. A.; VERNON, A.; QUINN, T. C.; POLK, F. B.; MODLIN, J. F.; YOLKEN, R. H. \& BARTLETT, J. G., 1988. Prevalence of enteric pathogens in homosexual men with and without acquired immunodeficiency syndrome. Gastroenterology, 94: 984-993.

LUNA, J. M.; MOURA, H. \& BRAZIL, R. P., 1987. Coccidioses em pacientes com AIDS/SIDA: estudo prospectivo no municípjo do Rio de Janeiro. Outu- 
bro de 1985 a novembro de 1986. X Congr. Soc. Bras. Parasitol. Resumos: 184.

MEYLR, E. A. \& JARROL, E. L., 1980. Giardiasis revicws and commentary, Am. J. Epidemiol, 111 : 1-12.

MINISTÉRIO DA SAÚDE, BRASIL, 1989. Boletim Epidemiológico - Ano II, no 8. Semana Epidemiológica, 5 a 8.

MIRANDA-SILVA, W.; GALVÃO-CASTRO, B.; BONECINE-ALMEIDA, M. G.; DANIEL-RIBEIRO, C. T.; SION, F. S. \& MORAES DE SÄ, C. A., 1988. Immunological abnormalities of acquired immunodeficiency syndrome and related disorders in patients from Rio de Janeiro, Brazil. Mem. Inst. Oswaldo Cruz, 83: 305-311.

MORAES, R. G., 1948. Contribuição para o estudo do Strongyloides stercoralis e da estrongiloidiase no Brasil. Rev. Serv. Esp. Saúde Públ., 1: 507-624.

MOURA, H.; LIMA, D. B.; VIOLA, J. P. B.; VALENTE, T. C.; FERNANDES, O. \& SILVA, S. P., 1987. Parasitoses intestinais em indivíduos do grupo de risco de AIDS/SIDA - necessidade de estabelecimento de rotina mínima para diagnóstico. $X$. Congr. Bras. Parasitol, Resumos: 63.

NAVIN, T. R. \& HARDY, M., 1987. Cryptosporidiosis in patients with AIDS (correspondence). J. Infect. Dis., 155: 150 .

PESSOA, S. B. \& MARTINS, A. V., 1980. Parasitolo. gia Médica - 11 ạ ediçāo - Guanabara Koogan, Rio de Janeiro, 872 p.

QUINN, T. C., 1986. Clinical approach to intestinal infections in homosexual men. Med. Clin. N. Amer., 70:611-634.
RITCHIE, L. S., 1948. Sedimentation technique for routine stool examinations. Bull. U. S. Army Med. Dept., 8: 326.

RODRIGUES, L. G. M. \& CHEQUER, P., 1988. SIDA no Brasil, 1982-1988. Bol. Of. Sanit. Panam., 105: 504-509.

SMITH, P. D.; LANE, C.; GILL, V. J.; MANISCHEWITZ, J. F.; QUINNAN, G. V.; FAUCCI, A. S. \& MASUR, H., 1988. Intestinal infections in patients with the acquired immunodeficiency syndrome (AIDS). Ann. Intern. Med., 108: 328-333.

SOAVE, R. \& ARMSTRONG, D., 1986. Cryptosporidium and Cryptosporidiosis. Rev. Infect. Dis., 8: 1012-1023.

SOAVE, R.; DANNER, R. L.; HONIG, C. L.; MA, P.; HART, C. C.; NASH, T. \& ROBERTS, R. B., 1984. Cryptosporidiosis in homosexual men. Ann. Intern. Med., 100: 504-511.

TURNER, J. A., 1985. Giardíase e infestaçōes por Dientameba fragilis. Clin. Ped. Amer. N., 4: 897 . 914.

WEIKEL, C. S.; JOHNSTON, L. I.; DESOUZA, M. A. \& GUERRANT, R. L., 1985. Cryptosporidiosis in Northeastern Brazil: association with sporadic diarrhea. J. Infect. Dis., 151: 963-965.

WORLD HEALTH ORGANIZATION (WHO), 1988. Interrelations of tropical discases and HIV infection. Report of an informal consultation held at the Kenya Medical Research Institute. Geneva: UDNP/World Bank/WHO Special Programme for Research and trainning in Tropical Diseases and the WHO Global Programme on AIDS, Document TDR/TD - HIV/87.3. 